\title{
Facework and multiple selves in apologetic metapragmatic comments in Japanese*
}

\section{Barbara Pizziconi}

Smooth social interaction requires that individuals engage in continuous negotiations with other individuals, in order to avoid or minimize social predicaments of various sort. Apologies are common, typical instances of remedial actions aimed at fixing intersubjective conflicts. We applogise for stepping on someone's toes or for being late, but also for verbal acts that have insulted or offended. All apologies admit the violation of some social commandment and signal a speaker's moral commitment to such commandment - or at least their awareness of its social importance ${ }^{1}$. But intersubjective conflict is not the only relevant conflict surfacing in an apology. Apologies proffered prior to the violation, for example, are relatively transparent signs of an intrasubjective conflict, that the utterer of an apology is attempting to reconcile. In the utterance: "forgive me for being blunt, but...", the apology is used prolectically; it is oriented to the projected, or anticipated, effects of an interactional faux pas which has not yet been committed (which is why apologies of this sort can be seen as a type of 'disclaimer', cf. Hewitt and Stokes 1975; Bell et al. 1984), and it admits a dissonance between two conflicting intentions: the intention to be blunt (for some contextually variable reasons) and the intention to abide by the social norm whereby bluntness is dispreferred. Far from appearing merely as a dysfunctional incoherence (Hermans 2002:153) or a blatant contradiction that calls into questions the sincerity or credibility of the apology (Benoit 1995: 30), apologies like this are accepted as legitimate currency in daily social exchanges. What makes this possible, I claim in this paper, is the model of the self that language users seem to uphold: one in which multiple and inconsistent 'agents' constituting the self cause some 
sort of intrasubjective tension. The self as a "heterogenous society" of multiple "I-positions" (Hermans, 2002) permeates personal narratives (Ochs and Capps 1996; Nair 2003) and is responsible for some very specific linguistic structures (Pang 2006). The linguistic expression discussed in this paper provides further support to the claim that such architecture of the self is the principal functional explanation for a great deal of self-reflective and 'meta' discourse (Pang 2006:iii).

In spite of the analytical distinction between language and metalanguage, it is generally accepted that no instance of language use would make sense without the assumption of some sort of 'meta' competence, including a metalinguistic, but also more,generally a metasemiotic, competence (Cameron, 2004). Given the 'commonsensical' nature of some aspects of such competence persistent frames of interpretation of social meanings and social activities - the interest of an exploration of the mechanisms of metacommunication lies in the possibility to uncover the ideologies we all take for granted in everyday discourse (Verschueren 2004: 65 ff.). This paper aims to illustrate this point by looking at the use of an apologetic formula in Japanese, which includes metalinguistic and evaluative comments. To the extent that such metalinguistic comments presuppose the speaker's awareness of the effects of language use and refer to canons of appropriateness (Lucy 1993: 17), they are fundamentally metapragmatic (Verschueren 2004: 55,58), and this is how I will refer to these expressions throughout. Such apologetic metapragmatic comments (AMC henceforth) exemplify one way in which speakers routinely deal with problematic talk: by embedding the voices of multiple selves in the apology, they can abjure problematic stances and orient themselves towards, and negotiate, normative social behaviour in everyday contexts. Selves can be 'fragmented' along different dimensions: past and present; male and female; id, ego and superego; good and evil, public and private (Ochs and Capps 1996:22); the tension between public 
and private traits of the self will be seen as the particular aspect foregrounded by AMC.

\section{Apologetic metapragmatic comments as aligning acts}

Although remedial action is at first sight other-directed (in terms of its symbolism of compensation), given the potential damage to the self-image and the consequent social sanctions caused by the violation of accepted norms of conduct, it is clear that it is also, importantly, an instance of 'selfimage restoration' (Benoit 1995), or a face-regulating tool enabling speakers to protect identities from the harm of such misalignements, Since AMC forestall potential negative typifications of one's action (Hewitt and Stokes 1975: 2), they must be regarded as 'alignment talk' (Bell et al. 1984).

Goffman (1971) notes that apologies involve two different processes: a substantive (or restitutive) one, in which the offender offers some sort of compensation, and a more ritual one, in which the offender is predominantly concerned with demonstrating that he is willing to disavow the offending self - and hence be again an acceptable member of the community (1971: 116). Perceptively capturing their metasemiotic nature, he claims that apologies represent a splitting of the self into a blameworthy part and a part that stands back and sympathises with the blame giving, and, by implication, is worthy of being brought back into the fold" (1971: 113).

In order to explore how this 'realignement' is achieved and to account more accurately for the subtle mechanisms operating in the use of AMC, I will first of all to recall here two Goffmanian constructs that I will utilize in the analysis of the Japanese apologies: the well known notions of face, and multiple speaker roles.

In Goffmanian terms (cf. Bargiela 2003), face has to do with the presentation of a desirable, commendable, acceptable public persona. It is "the positive social value an individual claims for himself by the line others 
assume he has taken during a particular contact" (Goffman 1967: 7) ${ }^{2}$. An individual's face is crucially a product of a 'social grant', to obtain which one has to work by adopting socially approved 'lines', or patterns of behaviour. How and to what extent facework is required depends on a number of factors, ranging from an individual's degree of commitment to canonical norms of the group to his/her relationship with other members of the group, but to the extent that community membership requires some sort of alignment, interaction requires active facework.

A recent discussion on metalanguage by Coupland and Jaworski (2004: 22) significantly points to Goffman and his emphasis on the "dramaturgical element of every day encounters", in which speakers are 'actors' and talk is 'performance', and hence 'face' is akin to a 'stage mask' "that people carefully select and "wear" to conjure up specific images and effects". Goffman explains the dynamism characterizing this performance as something that is possible thanks to the multiple roles in which we participate in talk. Thus he deconstructs the monolithic notion of speaker into three main roles: the author, the animator, and the principal (1981: 144). Various combinations of such roles allow us to discriminate between different types of participation formats. Whereas the animator refers to the 'utterer' and the author to the person 'designing' the ideas, feelings, or text expressed, the principal refers to the particular social role or social identity whose hat one wears at one time. Our ability to express, and detect, multiple 'voices' in this way, allows patterns of participation to move their deictic anchorage, to be projected to other times, spaces or settings. When quoting somebody else's words directly, I am the animator of the words but not the author. When I report what somebody said without quoting them literally (i.e. indirect speech), I am both animator and author. When I switch from a formal to an informal tone during a public lecture I continue to be both author and animator of my words, but this switch highlights the different capacity - the different 'principal' - which carries out those roles. When I 
say: "I'm speechless" while I clearly am not, I am foregrounding a "me" (an animator) different from the one animating the behaviour to which the comment putatively refers. This is obviously a theatrical description of a "me" that I don't fully expect others to believe (1981: 148), but which contributes to the interaction in some other, 'higher', removed, or more simply 'meta', role.

For Goffman, such embedding of roles (which he calls figures) is the device which allows us to manipulate the footing: "the alignment we take up to ourselves and others present as expressed in the way we manage the production and reception of an utterance" (1981: 128), in order to navigate the 'traffic of interaction', participate skilfully in social encounters and so manage perilous temporary misalignments.

We can try to tease these roles out by taking a second look at our 'bluntness' case: "forgive me for being blunt, but I think you are wrong". We could say that the speaker is the animator of both the apologetic preface and the main statement; he is also the author of both, but acts as if the author of the preface is 'hedging' the statement (about to be) made by the author of the main clause; this leads us to think that the speaker is acting in two capacities: an 'innocent' principal ${ }^{3}$ (responsible for the main statement "you are wrong") and a 'meta' principal (the one responsible for the hedging). The 'meta' principal, unlike the 'innocent' one, ostensibly upholds the interlocutor's perspective; this denotes a striving towards convergence and legitimizes/group membership; the display of metapragmatic awareness enables the principal to make an implicit claim of collaborativeness (put at risk by the bold remark) and social skilfulness, an obvious 'self-image restoration' device.

The participation format, following the Goffmanian framework, could be sketched out as follows:

$\begin{array}{lll} & \text { innocent narrative } & \text { meta narrative } \\ \text { Author } & \text { self in the observed world }(m e) & \text { self in the observing world }(I) \\ \text { Animator } & \text { self who says X } & \text { self who says something }\end{array}$


$\begin{array}{ll}\text { Principal social status } \mathrm{X} & \begin{array}{l}\text { about saying } \mathrm{X} \\ \text { social status } \mathrm{Y}\end{array}\end{array}$

Thus the 'splitting' and 'repudiating' of embedded selves is an ingenious rhetorical device that effectively allows speakers to smuggle potentially problematic moves into an exchange, while ostensibly upholding the community's norms.

\section{Japanese AMC}

Like all speech acts, apologies are culturally specific in form, content, frequency of use. A vast anecdotal and empirical literafure maintains that apologies are a pervasive feature of the Japanese language communicative style. Cases of pragmatic interference into and from Japanese involving apologetic remarks reveal language-specific conventions (Coulmas 1981: 89ff.; Ide 1998) and a predilection for explicit marking of apologies in Japanese. This is customarily explained in terms of preferred ethics: a strong concern with "acknowledging moral indebtedness" (Coulmas 1981: 88), or "being an imposition on others" (Heine et al., 1999: 779). Such sensitivity is further demonstrated by the considerable overlap of thanks and apologies ${ }^{4}$ : even receiving a benefit is likely to be coded as regretful indebtedness rather than straightforward gratitude (Coulmas 1981; Ide 1998), hence Japanese speakers can utter 'sorry' in situations where English or Italian speakers use 'thanks'. Comparative studies of remedial expressions find that while American speakers tend to give "priority to settlement of matters, [the] Japanese work towards sustaining reciprocal face-support between the interlocutors" (Kumagai 1993, quoted in Ide 1998: 511); that, together with a number of common strategies, Japanese female speakers apologise more than British English female speakers on behalf of husbands and children - a fact taken to demonstrate again a sociocentric, rather than egocentric orientation (Okumura and Wei 2000). 
Given the cultural significance of this speech act it is not surprising that, besides a large range of idiomatic expressions, Japanese also possesses a highly productive formulaic structure for $\mathrm{AMC}$, broadly translatable as: "Excuse me for saying this in such a $X X$ way/ Forgive me for putting it $X X$ ly, but...". This works like a template that speakers fill in with the contextually relevant qualification.

\begin{tabular}{|l|l|l|l|}
\hline$(x x) n a / i$ & hanashi & mooshiwake arimasen $(g a \ldots)$ \\
& & & \\
& talk, story, manner of speech & COPULA & unforgivable conjunction \\
\hline
\end{tabular}

TABLE 1 The structure of an apologetic metalinguistic comment in Japanese

The left part of the formula contains the phrase [ADJ + hanashi] and represents a metalinguistic comment, in that hanashi (lit. speech, talk) refers to the stretch of discourse in which the formula itself is embedded, preceded by a qualifying adjective. ${ }^{5}$ Thanks to this explicit evaluative element, speakers are able to orient the apology to the specific quality of the offending discourse An important consequence of this explicit labeling is that it extricates and objectifies speakers' moral, aesthetic, affective take on norms, values and beliefs (i.e. their framing of such norms); it also distils iconised modes of appropriate verbal interaction (cf. Coupland and Jaworski 2004:36), and so plays an important role in processes of enculturation and the perpetuation of normative discourse. For the researcher, this can sheds light on culturally sensitive lines of behaviour, and ideologies of linguistic conduct. Such underlying ideologies will be illustrated in the final part of this paper (see section 5) by looking at some of the collocations found within apologetic expressions.

Before proceeding to a discussion of the actual data, I would like to note the work of the Japanese linguist Seiju Sugito on sets of formulaic, 
routinely employed, metalinguistic Japanese expressions, which he labels chuushaku hyoogen (or 'commentary expressions'; Sugito 1983, 1999, 2001). He notes that although they target a variety of components of the speech event, they all operate on the basis of the same mechanism. A speaker can, for example, make a remark on the topic of the talk (ex. 1 below), the channel used (ex. 2), its timing (ex. 3), etc., but by operating such selection and evaluation $\mathrm{s} / \mathrm{he}$ generates implications of an interactional nature whose dominant functional orientation is invariably politenessrelated. Thus Sugito takes this commentary on an aspect of the speech event to be instrumental to the ultimate goal of displaying concern, regard for, or deference to, the speaker's interlocutor.

1. Konna koto wo iu beki ka dou ka wakarimasen ga,

I don't know if I should say this or not but...

2. Konna kantanna memo dewa shitsurei desunode, aratamete seishiki no bunshoo ni itashimasu.

This quick note is inadequate, so I shall rewrite it properly for you.

3. Yabun osore irimasuga, ...

Sorry for calling this late at night but.

The metalinguistic comments/discussed by Sugito appear generally as prefaces, and many crucially include an explicit apology with the structure illustrated in table the particular subgroup that this paper investigates. My analysis is in line with Sugito's in taking this particular string to encode some "pattern of interactional concern" (1999: August), but departs from it in considering deference, or politeness, to be at best only by-products of the interactional work. Sugito's analyis emphasises the effects on the hearer; mine, the effects on the speaker. Sugito claims that the hesitation shown in a sentence like 1 grows out of a concern not to look presumptuous in the face of an 'honourable' other: hence the metamessage the speaker wants the other to recognise is 'deference'. My claim is that the metamessage is first and foremost a statement about the self; deference is incidental. ${ }^{6}$ 


\section{Japanese AMC in computer-mediated communication: sources, method, data}

Although impression management is a pervasive concern not limited to the specific domain of computer-mediated communication, AMC are not equally distributed among genres. ${ }^{7}$ In contexts of oral, face-to-face, even public interaction, the use of the AMC of the kind discussed here is relatively spare. ${ }^{8}$ In contrast, the relatively liberal use of such expressions in computer-mediated communication - asynchronous and displaced interaction - is perhaps not surprising in light of the increased need to make one's stance more explicit.

The features of computer-based communication formats (e-mail, bulletin boards, discussion forums, support rooms etc.) are recognised to display huge variability which defies sweeping generalizations (Crystal 2001). But despite the presumed 'terseness' of Netspeak (language on the Net is not as contrived, elaborate or rich in formal salutations as in more traditional forms of written language), there is evidence that the importance of facework is not totally obliterated in virtual communication. The well known phenomenon of 'flaming' (or online disinhibition effect) has been linked to a number of psychological factors, among which: dissociative anonymity (you don't know me); invisibility (you can't see me); asynchronicity (no immediate feedback available to constrain emotional displays); solipsistic introjection (it's all in my head) and minimizing authority (no regulating figure) (Suler 2004). This highlights the regulating role of visual input and immediate interactional feedback, consciousness of the other and authoritative parameters - all necessary elements of facerelated considerations. Face-conscious users trying not to project false impressions during virtual encounters are forced to more explicit facework: indices of affective content such as emoticons are one such example; AMC another. Significantly, these devices appear to reinstate elements lost in the 
virtual environment: visual input (emoticons are mostly 'faces' coded with ever increasing complexity) ${ }^{9}$, or signals of self-positioning vis-à-vis significant others and significant authorities ${ }^{10}$ (the multiple selves instantiated in AMC are mobilised to provide such mappings).

The data for this study were collected from message boards (otherwise known as BBS, forums, web boards, discussion boards), or group support mailings on the web, with no pre-established restriction on topic, size, or participants' roles, but limited to threaded discussions ${ }^{11}$ (personal homepages were excluded ${ }^{12}$ ). The length of the messages was extremely varied, ranging from contributions of one or two lines to those many pages long. All contributions in a threaded discussion are embedded in a sequence and are by definition cross-referential, though not in any linear format. Typically, AMC work prospectively, i.e. they precede the text they refer to (acting as introductions), but (less frequently) they are also used retrospectively (referring to a stretch of diseourse uttered before).

dear XX, nice to meet you. ${ }^{13}$

....

I advise you to back up your data as soøn as you can. Assume it [the hard disk] could break down at any time (forgive me, $Y$ hope this doesn't tempt fate; lit.: forgive me for the inauspicious mention).

I don't know if this is relevant for you, but there is a summary of hard disk [issues] at the following link. .

With regards to the position within the larger unit of text in which they appear, they are frequent in openings but not unusual in closings, and they can also appear in any other position within a text - wherever and for whatever reason need arises for a 'realignment'.

More than 100 occurrences were collected by conducting a Google $\operatorname{search}^{14}$ of the string presented in table 1: “ $\sim i / \sim n a$ hanashi de sumimasen/mooshiwake arimasen" ("forgive me for speaking ly"). Many of the adjectives included in the string occurred repeatedly, and a list of these 'qualifications' is presented in table 2 in section 5. 
I will now return to the main argument introduced in section 1 and illustrate, with the three excerpts that follow, how speakers strategically exploit the multiple 'voices' of the self to project acceptable lines in spite of what could be regarded as substantial misalignments.

\section{AMC in context}

4.1 Cyclists $^{15}$

I would like to begin with a case where the interactional work seems fairly straightforward. The text is from a discussion page managed by a customer support team and displays what appears to be a very customer-friendly message, a sort of reply to a FAQ ('frequently asked question'). After a brief introduction in which the author announces the arrival of new bikes, he describes circumstances which present, for him, an interpersonal conundrum. The bike shop strongly recommends that customers who have asked for the bike to be disassembled for shipping verify with the staff at the shop, beforehand, that they are able to reassemble it. The author then commits a potential faux pas by suggesting that some customers may overestimate their ability to reassemble the bike by themselves, and he strongly encourages even such customers to consult with the shop. (The original text of the transcriptions can be found in the notes.)

"The FELT F55, the road-racer everybody is talking about has just been shipped. We had a few in stock and announced it on the web. We are over the moon for the flood of enquiries we received, especially last weekend. Answering queries about availability or prices was easy, but many of you stopped writing when we announced that as a rule we don't take mail orders. If you are still interested, please note that since many require a detailed answer we are lagging a bit behind with individual queries these days. We are then reporting here one section of our response for the sake of future enquirers on an issue of general interest.

[For customers who are unable to come to the shop but are confident about the maintenance]

Damage during shipment is a common risk and a cause of inconvenience. We would like to minimize the risks by disassembling the bike before shipping it, but we recommend that you visit us so we can ensure you are familiar with the 
assemblage procedures - just the basics we would like you to know not only to deal with this mail order but also as sport cyclists. Even experienced users are not always necessarily accurate. And even with the right knowledge and the right methods, the job is not always skilfully executed. Please forgive my presumptuous remarks (lit: Forgive me for this offensive statement $=$ shitsureina hanashi). This is difficult to verify on the phone or by mail. "

[http://www.biking.jp/page375.html]

We could see this AMC as a 'redressive action' in the Brown and Levinson's sense of a polite verbal strategy aimed at compensating for the preceding, impersonalised but not too veiled, criticism. This is after all an apology, intended to restore the (psychological) distance that the author has immodestly and dangerously reduced between him/herself and the customers. But apart from the difficulty of assessing the face threatening act at sentence level, I would like to claim that what has been directly threatened is not the customer's entitlement to deference (in which case we would of course be dealing with a politeness issue), but rather his entitlement to being (positively) seen as competent. Of course, the fact that competence may impinge on attributed status is obvious to us as it is the author, who qualifies his own action as offensive (shitsureina). That is, however, no more than a side effect, a by-product of this utterance's departure from the expected behaviour of a shop clerk. By stepping into the domain of criticism (indirect as it may be) the author has stepped into a role which the adressee(s) may well be unwilling to ratify, and that needs to be promptly 'realigned'. Note that in this case the author simply tries to reassure the customers that his insistence is after all in their interest: the change of footing enacted by the AMC attempts to say that one may be 'pushy' or 'bold' but does not intend to be subversive; in other words, by referring to a shitsurei (offensive) act, and hence implying knowledge of the social parameters whereby those acts could be construed as impolite, the AMC 'hedges' or constrains the interpretation of that act so that one can 
acknowledge 'impertinence' but not indifference or challenge to the social order.

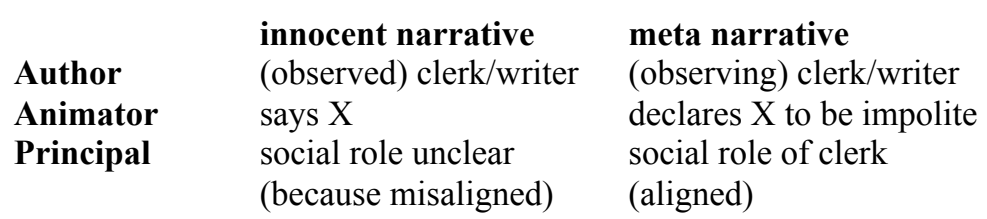

The additional figure embedded in the meta narrative is that of a second animator, who, by means of a realigning move (an apology), repairs the principal's role (compromised by virtue of the inappropriate criticism) and repositions it along the approved line. The principal can now claim to be acting appropriately, which importantly entails that the role of other participants is not challenged. Note that this does not require an 'objective', or shared, notion of what is expected. This very change of footing provides evidence for the audience that this author (the one in the 'meta' narrative) is capable and willing of framing (Goffman 1974: 10) the situation in the terms whereby clerks are not allowed to criticise customers. The audience may find this redundant, for example if they assume that the remark is driven by a professional concern (or if they did not perceive its potential criticism). But the AMC foregrounds the alignment to a publicly validated line: the criticism seems to be presented as the impulsive act of a 'naïve' self, while the hedging displays a heightened awareness of the public dimension. The balancing act (in fact a double-act) of warning incompetent customers and maintaining social credibility works thanks to the 'voicing' of two contrasting 'I-positions'.

But that not all AMC necessarily impinge on politeness will become clearer when we analyse cases which involve comments of a less 'moral' nature, and in which the roles are not as definite institutionally as in the first one.

4.2 Concerts $^{16}$ 
$>$ Contributor A introduces the topic of 'winter, the concert season' in a discussion board of musical interest. She talks about a violinist who has lost his sight. She comments that despite the lack of virtuosism the sound has a warm and healing quality. She then describes in detail some of the songs performed, and adds some comments on a specific CD. Finally, she writes:

Yesterday Mr. Kawabata said: "there are a lot of people in the world who would like to, but cannot attend concerts. Thus I am grateful for being able to perform here today, and that you are here to listen". I too felt blessed to be able to hear the good music of this world.

$>$ Contributor B Re: concert season

Coming to think of it, this is the concert season, isn't it? So far $Y$ have no plans...Uhm.. I'd like to hear something!

Mr. Kawabata is a violinist I too wanted to hear. Some pianists and violinists may have lost their sight, but their sensitiveness for sounds is impressive, isn't it? I am also always told by my teacher: "close your eyes when you play"( $\left.{ }^{\wedge \wedge} ;\right)$. What it means is that you can hear well how off-key your sound is. Sorry for this low-level considerations (teireberuna hanashi). (Silly me! :-))

Which concert shall I attend next year... $\delta$.

For now I just want to enjoy this season's musicians!

[http://www16.cds.ne.jp/ n hanga/yybbs/yybbs.cgi?mode=past]

The translation attempts to render the striking stylistic gap between the two interrelated messages; contribution $A$ is in a high register, phrased in syntactically complete units and informative in content; contribution B displays several lexical and syntactical colloquialisms, the rather emphatic tone is rendered graphically (note the emoticon and the musical notes as exclamation marks), moreover while A contributed with a comment of general interest, B barges in with several statements about herself and her wishes (and similarly ends her contribution). Although antecedent contributions also contained a mix of styles, and hence it is difficult to state unequivocally what is appropriate and what is not to this topic or context, the author of this latter contribution seems to indicate that she has become aware of some kind of 'dissonance'.

What is she doing when she suddenly qualifies her behaviour as 'low-level' and apologises for it? I think we could explain it along these lines: she has entered the scene with a self-referenced and self-oriented 
commentary. Although she is clearly doing that for an audience (as the addressee-oriented formal verb endings $-m a s u /-d e s u$, or the tag question in sugoi desu yo ne [impressive, isn't it?] demonstrate) her talk sounds very much like a soliloquy in that she happily gives vent to her own fancies and opinions without giving much thought as to whether they have any relevance for the audience. Moreover, it is possible that not only the content of her contribution but also her tone could be construed as thematically inappropriate: 'sober' language, rather than vernacular or emphatic Tanguage, is more commonly associated with classical music. She seems at this point to have stepped out of the 'line' (or one of the accepted lines) that such a context permitted or demanded. This entails the possibility that her talk may be received as unsophisticated but - more importantly - she risks being also judged as socially clumsy. ${ }^{17}$ So she now makes an attempt to recover an alignment to an expected line, but she cannot cancel the whole import of her contribution (unless she decided not to post it on the web, that is, or to recast it). She decides to go ahead with part of it (her message continues more or less in the same vein even after the AMC), but to attempt a partial rescue. Here however, there is no institutionally established social role to construe, and we are dealing with a case of self-image conceived in terms of the general attributes commonly associated with members of this particular community of practice ${ }^{18}$. Since the author goes ahead with a similar tone after the AMC we can only understand the remark as her being aware of and being prepared to bear responsibility for at least part of the misalignment this is not a 'true' or 'naïve' faux pas. The actual message of the 'meta' animator is something along these lines: "I am aware you may think I am being simple - and I may indeed be. But the reason I know that you may think this of me is because I do know what is de rigueur; I am indeed aware of what is proper and what is not and hence I am not socially incompetent" The apology is not substantial, of course, but instrumental to the positive claim to a certain self-image. However, this self-image (this "I") is not 
unitary. On the one hand we have individual psychological attributes, including innate talents and skills (what we may call private traits), on the other individual social attributes, including innate or learned talents and skills (what we may call public traits). So there seems to be an aspect of the self for which the author apologises (the private self which is "low-level") and one that is claimed by means of that very apology (the public self, which has communicative savvy). We can observe this in the participation framework:

$\begin{array}{lll}\text { Author } & \text { innocent narrative } & \text { meta narrative } \\ \text { (observed) forum participant } & \text { (observing) forum participant } \\ \text { Animator } & \text { says X } & \text { declares X to be banal } \\ \text { Principal } & \text { a novice contributor } & \text { a connoisseur }\end{array}$

This speaker attempts to claim a line not by indiscriminately adhering to the putative expected behaviour, but rather demonstrating that she (or at least one part of her self) is $\_$conversant with the parameters defining expected behaviour (by rhetorically referring to them). Ratification is again a prerogative of other participants, but the point is that the speaker strategically deploys the very metapragmatic awareness of the possible negative typification of his/her actions as a social skill with an interactional value. Moreover, unlike simple disclaimers (something along the lines of: "I know you may think this is low-level, but...") or 'sin licences' ("I realise you might think this is against the rules, but...", Hewitt and Stokes 1975: 5) AMC may indicate that stepping out of the expected lines is construed as a source of mutual, rather than personal, embarrassment ${ }^{19}$. That an apology is deemed an appropriate strategy to deal with such misalignements bears the implication that positive self-image, the face that one claims by such realigning moves, is not uniquely construed as self-enhancement but also as self-criticism (Heine et al. 1999). This is in line with social psychological work on Japanese specific aspects of self and the critique of an ethnocentric conception of the notion of 'positive self-regard' (ibid, for a review). 
I will return to a general discussion of the issue of self criticism in section 5; the next and final example offers further evidence of possible objects of self-criticism: acts and words deemed to bear little relevance for the interlocutor.

\title{
4.3 Friendship ${ }^{20}$
}

\begin{abstract}
$>$ Contributor A recounts how a person she met and befriended one year before ended up calling her every single day and with little regard for the circumstances which the call interrupted; moreover, the caller allegedly feels free to interrupt the call abruptly to take other incoming calls. A nevertheless declares to like the caller, declares to feel bad for being unable to sympathize, and asks fellow contributors advice on whether trying to speak to the caller might be the right thing to do.
\end{abstract}

$>$ Contributor B Re: what do you want to do next?

Dear Sindi

Please understand that this may not be the reply you wanted, as I don't know what kind of relationship you would like to have with your friend from now on (would you like to have a deeper relationship? have more distance?). In general, I think it is not acceptable to call only at-one's convenience, or not to call at all (or not allow others to call) when it is not. If one is not ready to acknowledge the good as well the bad sides of the other there can be no friendship. As a matter of fact, if you are not ready to do that, it is better to maintain a certain distance.

Forgive me for making a presumptuous (=katte) suggestion but I propose that:

- you explain the feelings of someone who is cut off by an incoming call

- you try to do that [the same, cut the call at your convenience, bp]

- you talk only for a set amount of time (roughly defined)

I am sorry again for these parochial (=katte) remarks.

I too (a man) have a friend (a man). We don't talk every day, but there has been a time when something similar happened. But he had some qualities which were more important than this. We are now more than $1000 \mathrm{~km}$ apart but we are still friends's, after 20 years.

[http://www.yomiuri.co.jp/komachi/reader/200111/2001111200003.htm]

The AMC in this exchange may at first seem rather puzzling. The contribution in question is a direct reply to A's query ad request for advice.

So what is B apologizing about and why is he qualifying his contribution as selfish/parochial/presumptuous? 
The interactional framework could be described as something like this:

\begin{tabular}{|c|c|}
\hline & innocent narrative \\
\hline Author & (observed) forum participant \\
\hline Animator & says X \\
\hline Principal & $\begin{array}{l}\text { is self-referenced } \\
\text { naïve contributor }\end{array}$ \\
\hline
\end{tabular}

\author{
meta narrative \\ (observing) forum participant \\ declares $\mathrm{X}$ to be self-referenced \\ is other-referenced \\ considerate counsellor
}

Like in the previous excerpts, the aspect of face that the AMC attempts to constitute is an acceptable public face. Katte means doing as one-pleases; something that suits one's convenience only; it qualifies a talk as selfreferenced, and a person as selfish and wayward. These are qualities which tend to carry social stigma, as socio-psychological and ethnographic literature on Japan rather consistently illustrates. The suggestions made by the contributor are potentially face threatening once face is understood as a mutual, interrelated concept which is damaged when this interpersonal link is severed. Personal opinions are one such way in which individual agency rather than co-operative action is potentially foregrounded. This is not to say that expressing personal opinions in Japanese is a behaviour that is invariably stigmatized, but rather that this particular speaker is alerted to the possibility (to a certain extent conventional and socially recognisable) that his suggestions are negatively construed as subjective and applicable only to his circumstances, rather than meaningful for the community. His metapragmatic condemnation of his act as self-referenced is only possible if one can recognise the relevant social value that is thereby endangered, in this case that of mutual co-operativeness and collective relevance. While face as a social trait is bound to be threatened by indifference to mutual and interrelated aspects of the self whatever the culture one treads in, these examples seem to point to the salience of alter-orientation and roleconsideration in the construction of acceptable stances in Japanese discourse. Moreover, taking care of the interpersonal dimension entails demonstrating a shifting and inclusive perspective; excuses for inadequate or inappropriate 
private traits take the shape of requests for indulgence and tolerance rather than self-enhancing justifications or denials.

\section{Some further remarks on Japanese face}

Social theory has rightly come to distrust assumptions of cultural homogeneity and unquestioning consensus. Similarly, it has been pointed out that facework theory has wrongly assumed that people are invariably concerned with appearing likable, or claim positive face (Tracy, 1990). People do not always attempt to adhere to stereotypical identities: AMC hint at ideal identities and roles that are systematically unmatched. In this sense they evidence the tension perceived by the self between his/her experience as an individual and as a member of a community (Mageo 2002: 358), and the attempt to reconcile that gap. Individuals may be more or less indifferent to social approval or normative behaviour (and no culture-wide generalization is therefore possible), but those who are not will try to ensure that individual inclinations do not cause irreparable damage to their public self-image. AMC allow distancing from such inclinations by means of the ostensive display of a wider, supra-individual perspective that intends to make amends. The mechanism behind such operation appears to be a folk notion of self as an aggregate of innocent private traits and metapragmatically competent public traits.

It has been pointed out that self-supportive moves in Japanese do not necessarily involve across-the-board self-enhancement but can make strategic use of self-criticism and self-depreciation (Heine et al., 1999). A further look at the evaluative comments contained in the AMC shows some interesting conceptualizations of socially reproachable stances.

ETHICAL/SOCIAL
AESTHETIC/ CONFIGURATIONAL
EMOTIONAL/ AFFECTIVE 


\begin{tabular}{|c|c|c|}
\hline $\begin{array}{l}\text { overt infringement of norms of conduct } \\
\text { shitsureina offensive, rude } \\
\text { bushitsukena ill-mannered } \\
\text { fukinshinna indiscreet } \\
\text { hazukashii embarrassing } \\
\text { akarasamana frank } \\
\text { related to social taboos } \\
\text { seiritekina physiological } \\
\text { fukitsuna inauspicious } \\
\text { biroona indecorous } \\
\text { henna weird } \\
\text { related to self } \\
\text { jiko chuushintekina self-centered } \\
\text { kattena selfish } \\
\text { watakushitekina one's own } \\
\text { kojintekina personal } \\
\text { rookaruna local } \\
\text { kooshi kondoona mixed personal \& public } \\
\text { keikentekina experiential } \\
\text { marena singular }\end{array}$ & $\begin{array}{l}\text { grading, ranking } \\
\text { shohotekina elementary } \\
\text { tanjunna simple } \\
\text { teijigenna rudimentary } \\
\text { teireberuna low-level } \\
\text { gehinna vulgar } \\
\text { sasaina trivial } \\
\text { exhaustiveness/orderliness } \\
\text { oomakana unspecific } \\
\text { oozappana approximate } \\
\text { chuutohampana incomplete } \\
\text { aimaina vague } \\
\text { matomarinai confused } \\
\text { sophistication } \\
\text { hironritekina atheoretical } \\
\text { kankakutekina impressionistic } \\
\text { ranboo coarse } \\
\text { complexity } \\
\text { mendoona complicated } \\
\text { muzukashii difficult } \\
\text { timing/mode of delivery } \\
\text { kyuuna sudden } \\
\text { toototsuna abrupt }\end{array}$ & $\begin{array}{l}\text { charged/uncharged } \\
\text { maniakkuna maniacal } \\
\text { oyabakana doting parent (-like) } \\
\text { karakuchina critical } \\
\text { bussoona alarming } \\
\text { majimena serious } \\
\text { katai dry, formal } \\
\text { di-puna deep (grave) } \\
\text { positive/negative } \\
\text { hikantekina pessimistic }\end{array}$ \\
\hline
\end{tabular}

TABLE 2 Qualifiers in top hundred occurrences of the apologetic metalinguistic comments ' i/na hanashi de mooshiwake arimasen'; (the categories proposed are by no means exclusive or exhaustive, but just suggestive; also, note that some expressions may be non-standard [e.g. kooshi kondoona]: I quote them as they appear in my data).

The range of the possible AMC, being contextually variable, is clearly open; contextual interpretation is cued by the specific qualification employed. Some qualifiers refer to the cognitive burden imposed on language processing (e.g. 'vague', 'abrupt', etc.); some refer to some contextually relevant problems ('atheoretical', 'low-level'); some explicitly refer to some shared evaluation of the transgression (i.e. 'offensive', 'inauspicious', etc.); others are less explicit, and interesting from a sociopsychological point of view: AMC that refer to notions of self seem to point to the importance of mutual consideration and a condemnation of selforientedness and insularity ('self-centered', 'personal', 'local'). Implicit as they are, AMC qualified in this way indicate the "hypercognized" relevance 
of intragroup care (or amae: Mageo 2002: 349, referring to the work of Doi 1981).

Morisaki and Gudykunst, discussing Japanese (sociocentric) conceptualizations of face, argue that although Goffman's face is socially negotiated it is not an interdependent, but an independent face (Morisaki and Gudykunst 1994). In contrast, they argue, what can 'gain and give face' in a Japanese discursive context are likely to be acts of recognition of mutual interconnection between individuals, above and beyond the individual traits of the self that can come into play. Whether any self (Goffmanian, Anglo-Saxon or 'western') can be truly 'independent' is arguable (Rosenberger 1989: 89), but the concern for mutual relational acknowledgement is a well-documented dominant orientation in Japanese discourse practices. ${ }^{21}$ AMC seem to be one of the ways in which such concern is manifested - and perpetuated - linguistically.

The analysis of AMC as self-presentation devices should not be taken to imply the speaker's indifference to the face of others. The interlocutor's face is always targeted in self-repairs, since self-positioning is always an act of altercasting. Our shop clerk in 5.1 had challenged a social dogma whereby customers are not to be criticised, doing which he had (re)framed the customer/clerk relationship as some other relationship; he then pays homage to the customers' face when he recasts himself in his role of shop clerk. The exuberant contribution of the music lover in 5.2 had called into question the other participants' persona by breaking the rules of that 'game' (its appropriate style, register, etc.). With the AMC, she restores the original, appropriate roles - the same mechanism applies, although institutional roles demonstrate this more clearly than non-institutional ones.

\section{Summary and conclusions}


This paper has maintained that evaluative metapragmatic comments are interventions which hedge, amend or constrain past or future inferences involving dispreferred typifications of conduct. Evaluative metapragmatic comments are therefore 'corrective'; apologies are remedial. The syncretism of these two strategies produces the conventional routine analyzed here, whose interactional goal has been posited to be the realignment of selfimages, reputations, identities, disrupted by some previous or looming faux pas. It is true, as claimed by Sugito, that metapragmatic comments can trigger considerations of politeness, to the extent that they display the speaker's regard for the hearer. However, the examples discussed here show that politeness is only one of several possible meanings emerging from facework.

Facework is seen as the primary raisond'etre of such operations. Since adult speakers are held responsible for their (verbal) behaviour, to the extent that they want to sustain socially integrated identities they must either avoid misaligned behaviour or they must provide credible justifications for any misalignement. Tension or clear mismatches between one's natural inclinations, desires, abilities, and the socially approved - or prestigious line of behaviour need to be justified. Speakers are not always able or willing to avoid such mismatches, and so AMC constitute a strategy to get on with one's manner of operation while apparently conceding ill-doing and asking forbearance. Thanks to the multiple 'voicing' (Silverstein 1993: 35; Coupland and Jaworski 2004: 27) - and the underlying composite architecture of the self - speakers are able to ask dispensations for parts of selves, which are likely to trigger unwanted typifications. Socially savvy selves can ask indulgence for privately inadequate selves. ${ }^{22}$

The workings of this corrective mechanism (with its underlying notion of a heterogenous self) may not fall within a speaker's awareness. However, the mechanism denotes a certain degree of reflexivity 
(Verschueren 2004: 55), or at least suggests that the normative identities that the speaker aims to project fall indeed within the sphere of objectifiable phenomena. Moreover, AMC constitute one way to further objectify parameters of 'face', because they target the behavioral lines that instantiate face, lift them from the realm of 'innocent' behavior and bring them to the front stage, where they can be accepted or challenged. AMC represent linguistic traces of a constantly ongoing self-monitoring activity (Verschueren 2004: 61) which is, at the same time, self-constitutive, and the evaluative metapragmatic comments we have observed carry out such selfmonitoring, and self-constitution, in the arena of morality.

Negative typifications can be prevented with disclaimers. Complementing the disclaimer with an apology is the signal of a specific morality: a preference for communicative modes that ostensibly display modesty and self-criticism.

\section{Notes}

* Jim O'Driscoll read part of an early draft of this paper and made some very pertinent comments; Nicholas Tranter kindly advised on my translations from Japanese. I thank both very much. None other than me is responsible for the final product.

1. See Goffman (1971) for an illustration of the multifarious ways in which speakers articulate apologies: explanations, excuses, pretexts ("excuses provided before or during the questionable act", 113) etc.; cf. also Benoit (1995).

2. Note however that the "positive' in Goffman's "positive social value" stands for 'socially sanctioned' (rather than a fixed, pancultural value) and 'socially desirable' (rather than a value somewhere above the middle of the self-evaluation spectrum). This is a necessary qualification in view of culturally (or community) variable conceptions of 'self' (Heine et al. 1999) and culturally (or community) variable canons of desirability, or appropriateness.

3. 'Innocent' is a term I borrow from Coupland and Jaworsky, referring to an idealised language devoid of any metalinguistic dimension, a language in which meanings would straightforwardly be embodied in linguistic forms, and be "uncontroversial, uncontested and 'innocent"' (2004: 15) - a language whose existence the authors decisively deny. Here I use the term to indicate the 'naiveté' attributed by one aspect of the self to another aspect of the self, a strategic device to rescue socially problematic stances.

4. Coulmas's paper argues that the two speech acts border, rather than contrast, with each other cross-linguistically. Japanese displays a relatively larger degree of overlap. 
5. The latter part of the string, containing the apology, is in fact optional. Metalinguistic comments are obviously possible which do not include explicit apologies, and correspond to 'disclaimers' (Hewitt and Stokes, 1975). However I maintain that even disclaimers are 'remedial' in some sense, even if that sense is only cognitive. Hedges of this type can, for example, redress problems of relevance, when they introduce a text which the author perceives as 'marked' (here possibly flouting a maxim of relevance):

[final utterance in a message in a discussion forum (machizukuri29) on urban planning. The reply discusses general theoretical issues, and then adds]:

yobunna hanashi desu ga, machi zukuri de yuumeina XXmachi wa, mata aratana hisaku wo ADJ talk COP ADV

nette iru nodesuka.

Incidentally (lit: 'talk in excess'), is that city of XX, that everybody knows for its urban development, still working at secret plans?

6. In doing so, I follow Watts (2003) in regarding politeness as behaviour "in excess", of what is expected from and directed to others and hence not a constant or necessary 'condition' of all interaction; impression management (that is, facework), on the other hand, is (Goffman 1967: 12).

7. Data consistent with those gathered from computer-mediated communication also emerged from spontaneous dialogic interactions in TV documentaries. Although these data have not been reported here due to their paucity (see note 8) at the current stage, they support the hypothesis that unplanned but natural, spontaneous discourse, as opposed to discourse in time-constrained interview conditions, is a possible/context for the use of expressions of this kind.

8. In addition to the question of explicit signalling discussed later in the section, the following points should also be noted with regards to the paucity of such uses in oral, public, face-to-face interaction. Despite some evidence in the first phase of the survey, as well native speakers intuition, that expressions of this kind ought to be numerous in public contexts of use, an extended search in talk/shows, topical debates, celebrity interviews, etc. yielded surprisingly few occurrences. Perhaps changes in language use in media and society may have made these rhetorical devices obsolete; or our idealised representations may have been no more than ideologically biased models of how Japanese ought to be spoken (in fact, many of the expressions discussed by Sugito are also classic entries on letter writing manuals, politeness manuals etc., typical examples of normative and prescriptive language use). Alternatively, this notable absence from spoken language could also be linked to processing: planned ys unplanned speech. This would explain the wider availability of such forms in written, as opposed to oral, interactions, and loose dialogic contexts as opposed to fast-tempo interviews. Data was indeed not difficult to find in the domain of computer-mediated communication.

9. See the rather elaborate 'faces' ( ${ }^{(1)}$ and $\left.{ }^{(2)}\right)$ and the genuflecting posture $\left({ }^{(3)}\right)$ in the following example, which also includes an AMC:

naruhodo $\left({ }^{\wedge}{ }_{-}\right)^{\circledR}$

sankusu desu $\left({ }^{\wedge} \_\wedge\right) /{ }^{(2)}$

mada ikutsuka oshiete kudasai. PC tsukau tokini iroiro betsuno kikai wo PC ni tsunaidari to ka shite imasuka? Shitsumon bakari de sumimasen. $\mathrm{m}(\ldots) \mathrm{m}$. ${ }^{3}$

I see $\left({ }^{\wedge}{ }_{-}\right){ }^{\oplus}$

Thanks $\left({ }^{\wedge} \_\wedge\right) /{ }^{(2)}$

Let me ask you something else: when you use a PC do you connect a lot of other devices to it? Sorry to ask so many questions. $\mathrm{m}\left(\_\right) \mathrm{m} .{ }^{3}[\mathrm{k} 14: 04810]$

10. To the extent that the participants to the forums that I present here share interests, purposes, perhaps sensibilities, language, resources and environment, albeit a virtual one, and are engaged in a joint enterprise which mutually binds them they are likely to constitute a bona fide community of practice (Wenger 1998). 
11. A threaded discussion is a set of interconnected electronic messages posted (asynchronously), archived, and accessible on a web site.

12. I have included one mailing from a support group affiliated to a shop, hence a format 'closer' to a homepage, as this allowed me to discuss institutional social identities (see section 4.1 'cyclists'). The discussion is not threaded but there is reference to previous emails in the message discussed.

13.「XXさん、初めまして。

いつ壊れてもいいように（不吉な話で申し訳ありません）、大事なデータは早めにバックアップされる ことをお勧めします。

参考になるかどうか分かりませんが、ハードディスクノイズについて山本さんがまとめておられますの でリンクしておきます。」

http://bbs.powerbook.org/qanda003/BBS_MSG_010621112046.html

14. See Pang 2006: 11 for references on the debate on the use of Google as a corpus. Google only allows a literal lexemes search, which was acceptable for my purpose

15.「ようやく入荷となりました今話題沸騰のロードレーサー、FELTF55 なのですが。入荷済 在庫あり、と当方 Web サイトでご案内したところ、特に先週末は沢山のお問い合わせをいただき、う れしい悲鳴です。在庫確認、価格などの返答メールならすぐに可能で、原則通販お断りを昖えすると、 それっきりとなってしまう方も多いのですが。それでもなおダメ元で再度ご連絡いただける方には、詳 細な個別の対応が必要な場合もあり、少し返答が滞りがちな昨日今日です。個別の対応とはいえ、ある 程度の傾向があるようで、これから問い合わせをしようとお考えの方にも参考になればと、皆様への返 信を一部掲載いたします。

【どうしても来店は不可能、でも自分で整備できるので大丈夫、といちお客様に対して】

不具合といえば、輸送中の破損のリスクも大きなものです。

実際、輸送することとなれば、リスクを小さくする意味でも一部分解した状態で棝包したいのですが、 これに伴う再組み立ての要領を一度お会いして確認したいとてころです。通販に限らず、スポーツ車の才 一ナーとしては、ぜひ覚えておいていただきたい程度の作業でもありますが。作業に関して、経験があ っても正確にできているとは限りません。正しい方法を知識として知っていても、上手にできていると は限りません。

失礼な話で申し訳ありません。これを確認するには、電話やメールのやり取りでは困難です。」 16.「... > 昨日、川畠さんが、「コンサートに行きたくても行けない人が世界には大勢います。こうし て今日、この場で演奏ができること、そいて聴いてくださる皆さんがいるという環境に感謝していま す。」と言っていましたが、私たちは伳界中の良い音楽に触れることができて本当に恵まれているな あ・・・感じました。

> そういえばコンサートシーズンなのかしらん? 私は全然予定無し〜。えーん、なにか聞きにいきた いですう。

川畠成道さん、わたしもいちど聴きたいと思っていたバイオリニストです アニストもバイオリニストもいらつしゃいますが、やっぱり音に対する感性がすごいですよね〜〜。私 もよく先生に「目をつぶつて弾け」と言われます。(^^;)つまり、目をつぶって聞けば自分の音はずれて るのよくわかるって話です。低レベルな話で申し訳ありませんが・・・。（爆）

来年は何聴きににそ亏かな。

今が旬の演奏家の音楽、うんと楽しみたいですね。」

17. Appropriateness is not measured only on broad social notions of status or deference (as in the previous example), but is context-specific. Here, contextual appropriateness refers to interrelated, wholistic ideas about the type of people, their language, topics, clothing that revolve around the theme of classical music; in other words, it is based on entire schema acquired through socialization. Conforming to such stereotypical schemas 'aligns' speakers to the social expectations; non-conforming produces dissonance, which may trigger inferences of an interactional kind about the social persona of the speaker (or author). AMC thus address and try to stop those inferences.

18. It is the very AMC which provides evidence of the ideal attributes of member of this community: the apology explicates the behavioural norm from which this speaker departed. According to Wenger (1998:81) participation to a community of practice is not just a "statement of purpose", but gives rise to "relations of mutual accountability" among those involved, which include "what matters and what does not... what to do and do not... what to justify and what to take for granted..." 
19. "When an incident occurs, the reality sponsored by the performers is threatened" (Goffman 1959: 296, my italics).

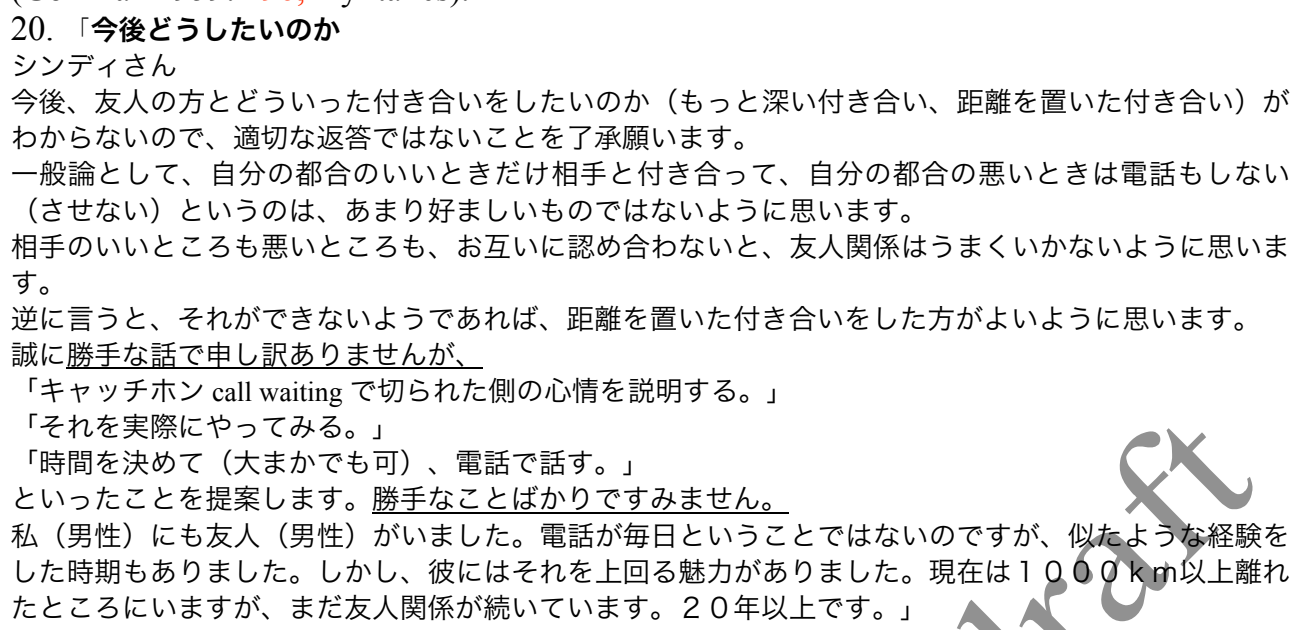

21. Senko K. Maynard (1997), discussing Japanese discourse styles and a Japanese level of 'social comfort', claims that "Japanese people normally try to achieve a comfortable level of interaction by physically and emotionally accommodating others, by giving gifts, by repeatedly expressing gratitude, by making others feel important and appreciated, by humbling and often blaming themselves in order not to upset others and so on". Similar views are presented in Kitayama et al. 1997 on the role of criticism. Needless to say, these are to be understood as socially disputed practices as any other one, and there is no doubt that social research needs to concern itself with how different subjectivities negotiate hegemonic values. See also Kasulis, 1998 and the papers presented there. Note that speaking of self-presentation techniques rather than self-representations of selves allows us to avoid the pitfalls of essentialist and stereotypical conceptualizations of selves (cf. Spiro 1993).

22. The validity of the metaphor 'self is a society of mind' would appear to be confirmed by a further correspondence in the mapping: that between the power differential (evidenced by the pragmatic judgement) exhibited by two contrasting positions in the self, and the power differentials existing between individuals in societies (Hermans 2002:148). However I prefer to subscribe to Pang's partitioned-narrative model, which treats the multiplicity of the self as real (Pang 2006:6).

\section{References}

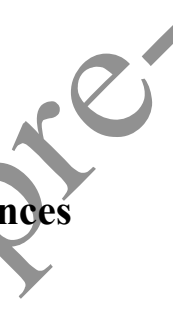

Bargiela-Chiappini, F. 2003. "Face and politeness: new (insights) for old (concepts)." Journal of Pragmatics 35(10-11): 1453-69.

Bell, R.A., Zahn C. and Hopper, R. 1984. "Disclaiming: A test of two competing views." Communication Quarterly 32 (1): 28-36. 
Benoit W.L. 1995. Accounts, Excuses and Apologies: A Theory of Image Restoration Discourse. Albany: State University of New York Press.

Cameron, D. 2004. Out of the bottle: the social life of metalanguage. In Metalanguage, A. Jaworski, N. Coupland and D. Galasinski (eds), 311-321. Berlin: Mouton de Gruyter.

Coulmas F. 1981. "Poison to your soul" - thanks and apologies contrastively viewed. In Conversational Routine, F. Coulmas (ed.). The Hague: Mouton.

Coupland, N. and Jaworski, A. 2004. Sociolinguistic perspectives on metalanguage: Reflexivity, evaluation and ideology. In Metalanguage - Social and Ideological Perspectives, A. Jaworski, N. Coupland, and D. Galasinski (eds), Berlin: Mouton de Gruyter.

Crystal, D. 2001. Language and the Internet. Cambridge: Cambridge University Press.

Doi, T. 1981. The Anatomy of Dependence. Tokyo: Kodansha International.

Goffman, E. 1959. The presentation of self in everyday life. London: Penguin.

Goffman, E. 1967. Interaction Ritual. Essays on Face-to-Face Behavior. London: Allen Lane.

Goffman E. 1971. Relations in Public: Microstructure of the Public Order. Harmondsworth: Penguin.

Goffman, E. 1974. Frame Analysis: An Essay on the Organization of Experience. Harmondsworth: Peregrine Books (Penguin). 
Goffman, E. 1981. Forms of Talk. Oxford: Blackwell.

Heine, S.J., Lehman, D.R., Markus, H.R. and Kitayama, S. 1999. Is there a universal need for positive self-regard? Psychological Review 106 (4): 766-794.

Heisler, T., Vincent, D. and Bergeron, A. 2003. Evaluative metadiscursive comments and face-work in conversational discourse. Journal of Pragmatics 35: 1613-1631.

Hermans Hubert J.M. 2002. The dialogical self as a society of mind: Introduction. Theory and Psychology 12(2):147-160

Hewitt, J.P. and Stokes, R. 1975. Disclaimers. American Sociological Review 40 (1): 1-11.

Ide, R. 1998. 'Sorry for your kindness: Japanese interactional ritual in public discourse. Journal of Pragmatics 29: 509-529 .

Jaworski, A., N. Coupland and D. Galasinski (eds), Metalanguage. Berlin: Mouton de Gruyter.

Kasulis, T.P. 1998. Introduction to part four: Self as image in Japanese theory and practice. In Self as Image in Asian Theory and Practice, R.T. Ames, with T.P. Kasulis and W. Dissanayake (eds.). Albany: State University of New York Press.

Kitayama, S., Markus, H.R., Matsumoto, H. and Norasakkunkit, V. 1997. Individual and collective processes of self-esteem management: Self-enhancement in the US and self-depreciation in Japan. Journal of Personality and Social Psychology 72: 1245-1267. 
Kumagai, T. 1993. Remedial interactions as face-management: the case of Japanese and Americans. In In Honor of Tokuichiro Matsuda, 278300. Tokyo: Iwasaki Linguistic Circle.

Lucy, J.A. 1993. Reflexive language and the human disciplines. In Reflexive Language: Reported Speech and Metapragmatics, J.A. Lucy (ed), 932. Cambridge: Cambridge University Press.

Mageo, Jeanette Marie. 2002. Toward a multidimensional model of the self. Journal of Anthropological Research 58/3: 339-365.

Maynard, S.K. 1997. Japanese Communication - Language and Thought in Context. University of Hawaii Press.

Markus, H.R. and Kitayama, S. 1991. "Culture and the self: Implications for cognition, emotion \& motivation" Psychological Review 98 (2): 224-253.

Morisaki, S. and Gudykunst, W. 1994. "Face in Japan and the United States." In The Challenge of Facework, S. Ting-Toomey (ed.), 47-94. Albany: State University of New York Press.

Nair, Bhaya Nair 2002. Narrative Gravity: Conversation, Cognition and Culture. Oxford University Press, New Delhi.

Okumura Keiko and Wei Lee 2000. The concept of self and apology strategies in two cultures. Journal of Asian Pacific Communication 10(1): 1-24. 
Pang Kam-yiu S. 2006. A Partitioned-Narrative Model of the Self: Its linguistic manifestations, entailments, and ramifications, Doctoral dissertation, University of Otago, New Zealand

Rosenberger, Nancy R. 1989. Dialectic balance in the polar model of self: the Japan case, Ethos 17(1): 88-113

Silverstein, M. 1993. "Metapragmatic discourse and metapragmatic function." In Reflexive Language: Reported Speech and Metapragmatics, J.A. Lucy (ed.), 33-58. Cambridge: Cambridge University Press.

Spiro, M.E. 1993. "Is the Western conception of the self "peculiar" within the context of the world cultures?" Ethos, 21/2: 107-153.

Sugito, S. 1983. Taiguu hyoogen toshite no gengo koodoo: chuuskaku toshite no shiten [The verbal behaviour of politeness: from the viewpoint of commentaries], Nihongogaku 2 (7).

Sugito, S. 1999. Tsutaekata no taiyoosei [Variety in communication], Eigo kyooiku (April to September)

Sugito, S. 2001. Taiguu hyoogen koodoo no wakugumi Danwa no Poraitonesu- Seventh International Symposium, National Language Research Institute, Tokyo, National Language Research Institute.

Suler, J. 2004. The Psychology of Cyberspace, http://www.rider.edu/ suler/psycyber/disinhibit.html 
Tracy, K. 1990. "The many faces of facework." In Handbook of Social Psychology, H. Giles and P. Robinson (eds), 209-226. Chichester: John Wiley.

Verschueren, J. 2004. Notes on the role of metapragmatic awareness in language use. In Metalanguage, A. Jaworski, N. Coupland and D. Galasinski (eds), 53-74. Berlin: Mouton de Gruyter.

Watts, R.J. 2003. Politeness. Cambridge: Cambridge University Press.

Wenger, E. 1998. Communities of Practice. Learning Meaning and Identity. Cambridge: Cambridge University Press. 